\title{
INTEGRATING MULTILINGUAL EDUCATION WITH CHILD FRIENDLY SCHOOLS TO DEVELOP AN EVIDENCE-REFERENCED MONITORING SYSTEM
}

\author{
Jack Frawley ${ }^{1}$ \\ Education Consultant, Australia
}

\begin{abstract}
:
The paper focuses on work undertaken in Cambodia to develop a monitoring framework that integrates Multi-lingual Education (MLE) with Child Friendly School (CFS) indicators. I begin by comparing CFS dimensions and indicators in Cambodia with those of the Philippines, and Nepal, and aligning MLE principles, arguments and foci with the CFS framework. I argue that an evidence-referenced system, such as the use of a rubric, is a model for giving meaning to achievement by linking it to evidence of growth or progress and measurement along a developmental continuum. Rather than just monitoring against a summative checklist, an evidence-based system describes the evidence so that progress can be benchmarked, and programs can be improved. Based on analysis of this research, I suggest an approach that could be used to reflect MLE indicators within the CFS framework, using an evidence-based rubric to monitor progress along a developmental continuum.
\end{abstract}

Keywords: Child friendly schools, multilingual education, indicators, evidence-referenced systems, assessment rubrics, Indigenous languages

\section{Introduction}

The Child Friendly School (CFS) concept was first used in a systematic way in the mid-1990s with the influence of UNICEF. Introduced in 1999 by UNICEF as a response to the global need for improvements in quality schooling, the CFS framework is driven by a child-rights philosophy that views the role of schools as promoting the development of the whole child (Godfrey et al., 2011). The CFS is based on the principles of children's rights as expressed in the Convention on the Rights of the Child, 1990 and other international human rights instruments and international declarations, including the Declaration of Education for All, 1990 (UNICEF, 2009). At the core of the CFS concept is the three key inter-related principles of child-centeredness, democratic participation and inclusiveness (UNICEF, 2009).

Cambodia was one of the earliest countries in South East Asia to introduce and then adapt the original CFS framework, first as a small pilot project in 2001 and then as a national

\footnotetext{
${ }^{1}$ Correspondence: PO Box 506, Coogee NSW 2034 Email: jwfrawley@icloud.com
} 
policy in 2007 (UNICEF, 2016). In order to monitor and evaluate school and classroom performance a school performance checklist was designed, developed and implemented (Chabbott, 2004). Currently the checklist is organised around five dimensions, although some countries have added a six th, with each dimension having several indicators.

Parallel to the development of CFS in Cambodia has been the work of CARE, which in 2003 established bilingual schools in six remote Indigenous communities in Ratanakiri (Noorlander \& Ven, 2008). Working in partnership with the government Ministry of Education, Youth and Sport (MoEYS) and other development partners including UNICEF, CARE developed and implemented a primary school multilingual education (MLE) model based on Indigenous languages that had been used for adult literacy. The aim of MLE was and is to increase ethnic minority children's access to, and the quality of, primary and secondary education. Since 2003, and under the under the government's Multilingual Education National Action Plan (MENAP, 2015-2018), MLE has been expanded to four additional north-eastern provinces of Mondul Kiri, Stung Treng, Kratie and Preah Vihear (MoEYS, 2015a). At the time of writing, a second MENAP (2019-2022) is under development to guide the next implementation phase of MLE.

For some time, CARE and UNICEF have discussed the need to monitor and evaluate MLE schools CFS frameworks to include MLE indicators. These indicators should be qualitative as well as quantitative, so that progress can be demonstrated and so that the program can react to needs. UNICEF (2006, p. 10) states that within the CFS context often 'a combination of both process and outcome indicators is needed, with local school committees continually reassessing the indicators themselves to ensure that higher standards are being sought and that friendliness is a dynamic, not fixed, state of being.' The same is required for MLE contexts. In 2016, I was employed as a consultant by CARE Cambodia to provide advice on how to incorporate MLE assessment in the CFS monitoring framework based on my previous research (Lee, Watt, \& Frawley, 2014), good practices in the region, and relevant research.

\section{Literature: Global Conventions and Declarations, Child Friendly Schools, and Multi- lingual Education}

I take a rights-based approach to the focus of this paper, and so begin with literature on global conventions and declarations that underlie policies and practices in MLE based on learners' home languages. I then review the CFS framework and the rationale for MLE and the use of first language instruction.

\section{Global Conventions and Declarations}

Global declarations and conventions affirm the right of Indigenous and ethnic minority children to an education that is provided in their first language. The United Nations Declaration of Human Rights states basic rights and fundamental freedoms to which all human beings are entitled. Article 26 states that everyone has the right to education. The United Nations Convention on the Rights of the Child is a human rights treaty which sets out the civil, political, economic, social, health and cultural rights of children. Article 29 states that children have the right to an education. Further, Article 30 states that:

In those States in which ethnic, religious or linguistic minorities or persons of indigenous origin exist, a child belonging to such a minority or who is indigenous shall not be denied the right, in community with other members of his or her group, to enjoy his or her own culture, to profess and practise his or her own religion, or to use his or her own language (UNHR, 1989)

The Declaration on the Rights of Indigenous Peoples affirms the minimum standards for the survival, dignity, security and well-being of Indigenous peoples worldwide and enshrines 
Indigenous peoples' right to be different. Concerning language, Article 13 states that Indigenous peoples have the right to revitalize, use, develop and transmit their languages, and writing systems. Additionally, Article 14 states that:

1. Indigenous peoples have the right to establish and control their educational systems and institutions providing education in their own languages, in a manner appropriate to their cultural methods of teaching and learning.

2. Indigenous individuals, particularly children, have the right to all levels and forms of education of the State without discrimination.

3. States shall, in conjunction with indigenous peoples, take effective measures, in order for indigenous individuals, particularly children, including those living outside their communities, to have access, when possible, to an education in their own culture and provided in their own language (United Nations, 2008)

The Dakar Education Declaration 2000 affirmed the principle of Education for All (EFA) as a global commitment to provide quality basic education for all children, youth and adults, ensuring "that all children, particularly girls, children in difficult circumstances and those belonging to ethnic minorities, have access to and complete, free and compulsory primary education of good quality" (EFA, 2007, p. 33). The EFA 2000 Assessment suggested a wide range of ways in which schools could respond to the needs of their pupils, including the provision of MLE for the children of ethnic minorities. The Declaration recommended that successful education programs require, amongst other things 'a relevant curriculum that can be taught and learned in a local language and builds upon the knowledge and experience of the teachers and learners'.

The United Nations Millennium Declaration was a commitment to a global partnership to reduce extreme poverty and it included a series of targets within a 2015 timeframe. This Declaration became known as the Millennium Development Goals (MDGs). Goal 2 aimed to achieve universal primary education with a target to ensure that all children everywhere completed a full course of primary schooling. The Sustainable Development Goals (SDGs) build upon the MDGs and converge with the post-2015 development agenda. The transformational pathways for SDGs include the process of scaling up good practice, and focusing on multi-stakeholder decision-making processes, rather than top-down approaches. SDG 4 ensures inclusive and quality education for all and promotes lifelong learning.

The vision of the UNESCO Incheon Declaration and Framework for Action 2030 is to transform lives through education. This is reflected in SDG 4. The focus of the Declaration, in part, is on efforts on access, equity and inclusion, quality and learning outcomes, within a lifelong learning approach. An indicative strategy is that by 2030 :

all young people and adults across the world should have achieved relevant and recognized proficiency levels in functional literacy and numeracy skills that are equivalent to levels achieved at successful completion of basic education. The principles, strategies and actions for this target are underpinned by a contemporary understanding of literacy not as a simple dichotomy of 'literate' versus 'illiterate', but as a continuum of proficiency levels. The required levels, and how people apply reading and writing skills, depend on specific contexts. Particular attention should be paid to the role of learners' first language in becoming literate and in learning. Literacy programs and methodologies should respond to the needs and contexts of learners, including through the provision of context-related bilingual and intercultural literacy programs within the framework of lifelong learning (UNESCO, 2015, p. 20). 
The Declaration further states that in multilingual contexts, where possible and taking into account differing national and subnational realities, capacities and policies, teaching and learning in the first or home language should be encouraged' (UNESCO, 2015, p. 13).

Child Friendly Schools (CFS). The CFS concept is grounded in these declarations and conventions and is driven by a child-rights philosophy that views the development of the whole child as central to the role of schools (Godfrey et al., 2012). UNICEF recognises that CFS models are grounded in local realities that limit the ability to design and implement ideal solutions, nevertheless the CFS framework is used by many countries globally and administered and managed by many national governments and NGOs, all of which have adapted the CFS to suit the local contexts (Godfrey et al., 2012).CFS apply the concept of Child Rights to education practice and management at the classroom and school level. The CFS policy for basic education is the fundamental approach for strengthening the quality of education for all students in primary and lower secondary schools. The basic CFS framework consists of the following five dimensions:

1. Proactively inclusive, seeking out and enabling participation of all children and especially those who are different ethnically, culturally, linguistically, socio-economically, and in terms of ability;

2. Academically effective and relevant to children's needs for life and livelihood knowledge and skills;

4. Healthy and safe for, and protective of, children's emotional, psychological, and physical well-being;

5. Gender-responsive in creating environments and capacities fostering equality;

6. Actively engaged with, and enabling of, student, family, and community participation in all aspects of school policy, management and support to children. (UNICEF, 2006, p. 1)

Some countries have simplified the language of the dimensions; others have separated dimension five into two separate dimensions, for example in Sri Lanka: '5. Actively engaged with students, families and communities'; '6. Supported by child friendly systems, policies, practices and regulations' (Sri Lanka, MOE, 2008, p. 2). In Cambodia, dimension six is stated as:

6. 'The National Education System supports and encourages schools to become more child friendly' (MoEYS, 2007).

The CFS dimensions are viewed as being 'necessary and mutually reinforcing conditions of CFS success', and a CFS school is child-friendly when all of the dimensions are addressed, and 'the ability to be child-friendly on each dimension is enhanced by action on the others' (UNICEF, 2006, p. 1). In Nepal, a further dimension has been added to address minimum and expected indicators for teaching and learning in the Mother Tongue with the indicators covering the areas of needs, materials, teacher training, infrastructure, and other activities (Government of Nepal, 2010).

\section{Multi-lingual Education}

Benson (2002) states that the use of first language instruction in school is the most efficient for early literacy upon which to base learning of additional languages and literacies as well as other curricular content. Some of the advantages and benefits of first languagebased education (CARE, 2015; Lee et al., 2014; Benson, 2005; Kosonen, 2005) are that:

- children have access to education in a language they understand and speak well; 
- children develop literacy skills most efficiently in a familiar language leading to higher literacy rates;

- children develop cognitive skills and master content material when they are taught in a familiar language providing equal opportunities to learn all subjects taught at school; ;ispep:

- the transfer of linguistic and cognitive skills;

- children's confidence, self-esteem, and identity are strengthened by the use of their first language, leading to increased motivation, engagement and initiative; iste-pi]

- first-language-based education often leads to improved access to schooling, decreased repetition and dropout, and enhanced gender equity;

- ethnic minority languages and culture are not lost;

- ethnic minority teachers are trained and receive employment as primary and early childhood development teachers;

- ethnic minority parents and communities are able to participate more in their children's education;

- teachers are better to assess the real learning achievement instead of one based on low language proficiency;

- student learning can be accurately assessed when students can express themselves allowing teachers to diagnose progress, further learning needs, and resources; and,

- students become bilingual and bi-literate and are able to understand, speak, read and write in more than one language.

Pinnock et al., (2011, p. 24) provide some arguments to convince political and educational leaders to support MLE. These are summarized here as:

- high performance in education and key languages is vital for national development;;

- education can only be effective when it is based around how children learn;

- most rural children's only chance of learning a second language well is to have multilingual basic education, embedded in a language they use in daily life; i[ i-

- funds spent on upgrading teachers' performance are wasted if teachers cannot be understood by students; is: íp.]

- equity in education is vital for stability and growth;s

- MLE can be done well if it is built on ongoing education reforms and if it takes a long-

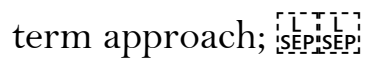

- improvements are likely to be seen in significantly improved primary school attendance and retention; and,

- changes will be felt in children's more positive experience of school, and greater confidence in education. iscepi

Supporting good quality MLE requires a focus on teachers, curriculum development, learning materials, assessment, support and participation (Lopez, 2012; Pinnock et al., 2011). For teachers and teacher training this means they should have a good understanding of child development and child-centred teaching methods; are placed in areas where they speak the same language as children; have their local, national and international language skills recorded by teacher training institutions and ministry of education; are encouraged to collaborate with local community members to promote communication and learning for children; and, are provided with timely, relevant and a good standard of pre-service, in-service and on-going training. Curriculum development for language learning needs to be an ongoing process that is negotiated with the community and includes their perspectives and worldviews. Learning and literacy materials are locally produced in the child's first language 
and are informed by relevant cultural content. Language assessment and testing focuses on communicative skills and understanding and is, for the most part, conducted in the local language using adequate and culturally sensitive and linguistically appropriate measurement. There are clear policies, guidelines, and budgets to support MLE efforts, and responsibility is shared with parents and the community, who are welcomed to be involved in the different stages of educational management. Community participation helps to establish adequate links and bridges between what happens in a school and the child's real world.

\section{Methodology}

The purpose of the consultancy on which this paper is based was to provide advice on how to incorporate MLE assessment in the CFS monitoring framework based on my previous research (Lee, Watt, \& Frawley, 2014), good practices in the region, and relevant research. I conducted a desk-based review of all existing documentation to synthesize the relevant data in order to undertake content analysis. Documents included, but were not limited to research and evaluation reports, manuals and policy documents peer-reviewed journal articles, and book chapters. The content analysis used a directed approach and was guided by a structured process that included identifying the data, selecting a coding approach, sorting and analysing, and drawing conclusions. An in-between coding approach began immediately with the predetermined broad codes of CFS indicators, and CFS assessment. The latter was adjusted to CFS indicator assessment approaches.

\section{Findings}

\section{CFS indicators}

The data analysis showed that CFS dimensions remain constant, although components and indicators may differ across regions that were sampled for this research. As noted earlier, the CFS framework dimensions are informed by the five principles of inclusiveness; safe, health and protective environments; effectiveness; democratic participation; and, gender responsiveness. From these principles, and using Cambodia as an example five dimensions ${ }^{2}$ have been developed and are generally expressed as:

1. All children can enrol (inclusiveness)

2. Effective learning (effectiveness)

3. Health, safety and child protection (safe, healthy and protective environments)

4. Gender sensitivity response (gender responsiveness)

5. Involvement of children, their families and community (democratic participation)

The analysis of three countries ${ }^{3}$ that have both a CFS framework and an established MLE program - Cambodia, the Philippines and Nepal - demonstrates how the six dimensions described by UNICEF are addressed at the component level and as indicators, with selected examples (Table 1). The dimension statements are those listed by UNICEF (UNICEF, 2006), while the components and indicators are verbatim extracts from each country's CFS monitoring framework which has been developed at the country level. These examples show the contrast between countries in terms of the level of detail for the components and corresponding indicators. The examples from Nepal are brief, while the examples from Cambodia have a greater depth.

\footnotetext{
2 As noted earlier, the Cambodian MoEYS added a sixth dimension: The National Education System supports and encourages schools to become more child friendly' (MoEYS, 2007).

3 These three countries are chosen because they each have an established MLE policy.
} 
Table 1

Examples of CFS components and indicators from Cambodia, the Philippines and Nepal aligned with the UNICEF defined CFS dimensions

\begin{tabular}{ll}
\hline CFS & Statement: Proactively inclusive, seeking out and enabling \\
Dimension: & $\begin{array}{l}\text { participation of all children and especially those who are different } \\
\text { Inclusiveness } \\
\text { ethnically, culturally, linguistically, socio-economically, and in terms } \\
\text { of ability (UNICEF, 2006, p.1) }\end{array}$
\end{tabular}

\begin{tabular}{|c|c|c|}
\hline Country & Component & Indicator \\
\hline Cambodia & $\begin{array}{l}\text { Identify pre-school and school-age } \\
\text { children with disability through } \\
\text { community mapping and school } \\
\text { enrolment campaigns, using specific } \\
\text { screening tool and provide } \\
\text { appropriate service for needed } \\
\text { support. }\end{array}$ & $\begin{array}{l}\text { Establish referral system to } \\
\text { community-based rehabilitation } \\
\text { services, hospital or NGO for follow- } \\
\text { up after identification of children } \\
\text { with disability. }\end{array}$ \\
\hline Philippines & $\begin{array}{l}\text { Encourage } \\
\text { completion. }\end{array}$ & $\begin{array}{l}\text { School has a master list of all school- } \\
\text { aged children in the community, } \\
\text { whether enrolled or not. }\end{array}$ \\
\hline Nepal & On access. & $\begin{array}{l}\text { Based on disability provision of } \\
\text { supportisepifor all children with } \\
\text { disability for access to school. }\end{array}$ \\
\hline $\begin{array}{l}\text { CFS } \\
\text { Dimension: } \\
\text { Effectiveness }\end{array}$ & \multicolumn{2}{|c|}{$\begin{array}{l}\text { Statement: Academically effective and relevant to children's needs for } \\
\text { life and livelihood knowledge and skills (UNICEF, 2006, p.1) }\end{array}$} \\
\hline Country & Component & Indicator \\
\hline Cambodia & $\begin{array}{l}\text { Ensure curriculum, students' } \\
\text { textbooks and teacher manuals for } \\
\text { all subject areas at all grade levels. }\end{array}$ & $\begin{array}{l}\text { Complete and disseminate new } \\
\text { curriculum for all subject areas on a } \\
\text { regular basis. }\end{array}$ \\
\hline Philippines & $\begin{array}{l}\text { Ensure children's high academic } \\
\text { achievement and success. }\end{array}$ & $\begin{array}{l}\text { Schools provide each student with a } \\
\text { complete set of textbooks. }\end{array}$ \\
\hline Nepal & Educational materials available. & $\begin{array}{l}\text { Locally prepared reading materials } \\
\text { including textbooks made available }\end{array}$ \\
\hline $\begin{array}{l}\text { CFS } \\
\text { Dimension: } \\
\text { Safe, healthy } \\
\& \text { protective } \\
\text { environments }\end{array}$ & \multicolumn{2}{|c|}{$\begin{array}{l}\text { Statement: Healthy and safe for, and protective of, children's } \\
\text { emotional, psychological, and physical well-being (UNICEF, 2006, } \\
\text { p.1). }\end{array}$} \\
\hline
\end{tabular}

\begin{tabular}{|c|c|c|}
\hline Country & Component & Indicator \\
\hline Cambodia & $\begin{array}{l}\text { Improve annual health checks for all } \\
\text { students and school staff in all public } \\
\text { primary and lower secondary } \\
\text { schools. }\end{array}$ & $\begin{array}{l}\text { Provide adequate and safe water } \\
\text { sanitation (toilets, garbage) services } \\
\text { for each school. }\end{array}$ \\
\hline Philippines & $\begin{array}{l}\text { Enhance children's health and well- } \\
\text { being. }\end{array}$ & $\begin{array}{l}\text { Schools serves and sells healthy and } \\
\text { nutritious food. }\end{array}$ \\
\hline Nepal & Healthy environment. & $\begin{array}{l}\text { Appropriate arrangements made at } \\
\text { school to avoid water stagnation. }\end{array}$ \\
\hline
\end{tabular}




\begin{tabular}{|c|c|}
\hline $\begin{array}{l}\text { CFS } \\
\text { Dimension: } \\
\text { Gender } \\
\text { responsive- } \\
\text { ness }\end{array}$ & $\begin{array}{l}\text { Statement: Gender-responsive in creating environments and } \\
\text { capacities fostering equality (UNICEF, 2006, p.1). }\end{array}$ \\
\hline Country & Component \\
\hline Cambodia & $\begin{array}{l}\text { Promote school, family and Gender concepts in curriculum and } \\
\text { community awareness of and school activities. } \\
\text { responsibility for the provision of } \\
\text { education for both girls and boys in } \\
\text { an equitable manner. }\end{array}$ \\
\hline Philippines & $\begin{array}{ll}\text { Guarantee safe and protective spaces } & \begin{array}{l}\text { School has a policy against } \\
\text { discrimination with regard to } \\
\text { for children. }\end{array} \\
\text { gender. }\end{array}$ \\
\hline Nepal & $\begin{array}{l}\text { Scholarship has been provided for } \\
50 \% \text { of girls. }\end{array}$ \\
\hline $\begin{array}{l}\text { CFS } \\
\text { Dimension: } \\
\text { Democratic } \\
\text { participation }\end{array}$ & $\begin{array}{l}\text { Statement: Actively engaged with, and enabling of, student, family, } \\
\text { and community participation in all aspects of school policy, } \\
\text { management and support to children (UNICEF, 2006, p.1). }\end{array}$ \\
\hline Country & Component \\
\hline Cambodia & $\begin{array}{l}\text { To encourage community } \\
\text { engagement in the operation of } \\
\text { schools and the quality of education. }\end{array}$ \\
\hline Philippines & $\begin{array}{l}\begin{array}{l}\text { Mobilise community support for } \\
\text { education. }\end{array} \\
\text { and Pchool has a written plan of action } \\
\text { Association that has elected leaders } \\
\text { who meet regularly. }\end{array}$ \\
\hline Nepal & $\begin{array}{l}\text { Some parents come to school to } \\
\text { know about their children's } \\
\text { progress. }\end{array}$ \\
\hline
\end{tabular}

\section{CFS assessment approaches}

The analysis of the data shows that assessment within the CFS monitoring framework is about checking the 'bottom line' in order to see if the school is making a difference to the provision of quality education and learning. The CFS assessment process has two parts: monitoring and evaluation. CFS monitoring involves collecting information over time and analysing that information to provide feedback that will improve the program. The CFS monitoring process requires:

1. establishing indicators on processes and outcomes;

2. establishing procedures and systems to collect information on these indicators;

3. developing tools and the procedures for collecting and recording the information;

4. analysing the information; and,

5. using the information to improve program planning, performance, and, thus, outcomes (UNICEF, 2006, p. 5).

Evaluation is the systematic and objective assessment of an ongoing program with a focus on performance against program objectives, accomplishments, progress, and outcomes 
(UNICEF, 2006). The sample countries of Cambodia, the Philippines, and Nepal use checklists to determine if the CFS indicators are being met, in this case for the dimension of democratic participation (Figs. 1, $2 \& 3$ ). These examples can be best described as summative assessment checklists.

\section{Figure 1}

CFS Checklist Cambodia (MoETS, 2015b)

\begin{tabular}{|c|c|c|c|c|c|c|c|c|c|}
\hline \multirow[t]{2}{*}{ Results } & \multirow{2}{*}{$\begin{array}{l}\text { Indicators or } \\
\text { activities }\end{array}$} & \multicolumn{3}{|c|}{ Situation } & \multicolumn{5}{|c|}{ Achievements } \\
\hline & & Yes & No & $\mathrm{N} / \mathrm{A}$ & Good & Fair & Average & $\begin{array}{l}\text { Below } \\
\text { average }\end{array}$ & Comment \\
\hline \multicolumn{10}{|c|}{ 1. All students enrolled for school. } \\
\hline \multirow{3}{*}{$\begin{array}{l}\text { Students' } \\
\text { parents } \\
\text { participated } \\
\text { in } \\
\text { monitoring } \\
\text { and } \\
\text { motivating } \\
\text { learning }\end{array}$} & $\begin{array}{l}\text { 1. Student's } \\
\text { family } \\
\text { received Book } \\
\text { Record every } \\
\text { month and } \\
\text { monitor } \\
\text { children's } \\
\text { homework. }\end{array}$ & & & & & & & & \\
\hline & $\begin{array}{l}2 . \quad \text { Students } \\
\text { family and } \\
\text { communities } \\
\text { participated in } \\
\text { gathering } \\
\text { children to } \\
\text { study and } \\
\text { school's } \\
\text { meetings. }\end{array}$ & & & & & & & & \\
\hline & $\begin{array}{l}\text { 3. Students' } \\
\text { parents } \\
\text { attended } \\
\text { scholarship } \\
\text { and breakfast } \\
\text { programs. }\end{array}$ & & & & & & & & \\
\hline
\end{tabular}

\section{Figure 2}

CFS Checklist Philippines (UNICEF, 2006)

\begin{tabular}{|l|l|l|l|}
\hline Indicators & Evident & $\begin{array}{l}\text { Not } \\
\text { evident }\end{array}$ & Remarks \\
\hline $\begin{array}{l}\text { GOAL \#1: Encourage children's participation in school and } \\
\text { community }\end{array}$ & & & \\
$\begin{array}{l}\text { What your school should have or should be doing: } \\
\text { - Your school has a working student government. }\end{array}$ & & \\
\hline $\begin{array}{l}\text { Your school involves students in meetings and } \\
\text { planning sessions that concern their well-being. }\end{array}$ & & \\
\hline $\begin{array}{l}\text { Your school encourages its students to get involved } \\
\text { in community work. }\end{array}$ & & & \\
\hline $\begin{array}{l}\text { Your school has a mechanism or mechanisms such as } \\
\text { school publication, students' bulletin board, or } \\
\text { opinion box for pupils to express their opinions about } \\
\text { school and community issues. }\end{array}$ & & & \\
\hline
\end{tabular}


Figure 3

CFS checklist Nepal (Government of Nepal, 2010)

\begin{tabular}{|c|c|c|c|c|c|c|c|c|c|c|c|c|c|c|c|c|}
\hline \multirow{2}{*}{$\begin{array}{l}\text { Participation of } \\
\text { local community } \\
\text { in the school }\end{array}$} & \multicolumn{4}{|c|}{ District $1^{4}$} & \multicolumn{4}{|c|}{ District 2} & \multicolumn{4}{|c|}{ District 3} & \multicolumn{4}{|c|}{ District 4} \\
\hline & 4 & 3 & 2 & 1 & 4 & 3 & 2 & 1 & 4 & 3 & 2 & 1 & 4 & 3 & 2 & 1 \\
\hline $\begin{array}{l}\text { Parents } \\
\text { participation }\end{array}$ & 1 & 3 & 1 & 1 & 4 & 2 & $\mathrm{O}$ & $\mathrm{O}$ & 2 & 3 & O & 1 & 3 & 3 & $\mathrm{O}$ & $\mathrm{O}$ \\
\hline $\begin{array}{l}\text { Cooperation and } \\
\text { support from } \\
\text { local bodies }\end{array}$ & $\mathrm{O}$ & 1 & 4 & 1 & 1 & 4 & $\mathrm{O}$ & 1 & 2 & $\mathrm{O}$ & 2 & 2 & $\mathrm{O}$ & 3 & 2 & 1 \\
\hline $\begin{array}{l}\text { Professional } \\
\text { support from } \\
\text { resource person } \\
\text { to promote the } \\
\text { child friendly } \\
\text { school and } \\
\text { learning } \\
\text { environment }\end{array}$ & $\mathrm{O}$ & 3 & 1 & 2 & 2 & 4 & $\mathrm{O}$ & $\mathrm{O}$ & 1 & $\mathrm{O}$ & 3 & 2 & 3 & 1 & 2 & $\mathrm{O}$ \\
\hline
\end{tabular}

\section{Discussion}

I have aligned MLE principles, arguments, and focus (CARE, 2015; Lee et al., 2014; Benson, 2005; Kosonen, 2005, Lopez, 2012; Pinnock et al., 2011) with the six CFS dimensions (UNICEF, 2006). In this alignment, I have made a judgment to whether there is a 'fit' of the principles, arguments and focus to the CFS dimensions. This 'fit' takes into consideration what is being described by the dimension and the intent of the principle, argument and/or focus. For example, CFS dimension 1 essentially upholds the Declaration on the Rights of Indigenous Peoples, especially regarding Article 14 where children should have access, when possible, to an education in their own culture and provided in their own language.' The MLE principle that ethnic minority languages and culture are not lost is, therefore, in close alignment with the CFS dimension.

Table 2

MLE best practice alignment with CFS dimensions

CFS Dimension: Statement: Proactively inclusive, seeking out and enabling Inclusiveness participation of all children and especially those who are different ethnically, culturally, linguistically, socio-economically, and regarding ability (UNICEF, 2006,p. 1).

MLE indicators $\quad$ - ethnic minority languages and culture are not lost

- children have access to education in a language they understand and speak well

\begin{tabular}{ll}
\hline CFS Dimension: & Statement: Academically effective and relevant to children's needs \\
Effectiveness & for life and livelihood knowledge and skills (UNICEF, 2006,p. 1). \\
$M L E$ indicators & $\begin{array}{l}\text { children develop literacy skills most easily in a familiar language } \\
\text { leading to higher literacy rates }\end{array}$ \\
\hline
\end{tabular}

\footnotetext{
${ }^{4}$ Six (6) schools from each district were taken as sample. Each column represents the number of schools having degree of strength in respective scale. 4: Excellent, 3: Good, 2: Low, 1: Poor.
} 
- children develop cognitive skills and master content material when they are taught in a familiar language providing equal opportunities to learn all subjects taught at school

- transfer of linguistic and cognitive skills is facilitated

- teachers are better to assess the real learning achievement instead of one based on low language proficiency

- student learning can be accurately assessed when students can express themselves allowing teachers to diagnose what has been learned, what remains to be taught and which students need further assistance

- students become bilingual and bi-literate and are able to understand, speak, read and write in more than one language.

- education can only be effective when it is based around how children learn

- most rural children's only chance of learning a second language well is to have multilingual basic education, embedded in a language they use in daily life

- learning and literacy materials are locally produced in the child's first language and are informed by relevant cultural content

- language assessment and testing focus on communicative skills and understanding and is conducted in the local language using adequate and culturally sensitive and linguistically appropriate measurement

CFS Dimension: Statement: Healthy and safe for, and protective of, children's Health, safety and emotional, psychological, and physical well-being (UNICEF, protection 2006,p. 1).

MLE indicators - children's confidence, self-esteem and identity are strengthened by the use istepiof their first language, leading to increased motivation, engagement and initiative;

- changes will be felt in children's more positive experience of school, and greater confidence in education

\section{CFS Dimension: Statement: Gender-responsive in creating environments and Gender responsiveness \\ MLE indicator capacities fostering equality (UNICEF, 2006,p. 1). \\ - first-language-based education often leads to improved access to schooling, decreased repetition and dropout, and enhanced gender equity}

CFS Dimension: Statement: Actively engaged with, and enabling of, student, Democratic participation family, and community participation in all aspects of school policy, MLE indicators management and support to children (UNICEF, 2006,p. 1).

- ethnic minority parents and communities are able to participate more in their children's education

- are encouraged to collaborate with local community members to promote communication and learning for children

- curriculum development for language learning needs to be an ongoing process that is negotiated with the community and includes their perspectives and worldviews 
- there are clear policies, guidelines and budgets to support MLE efforts, and responsibility is shared with parents and the community

- community participation helps to establish adequate links and bridges between what happens in a school and in the child's real world

\begin{tabular}{ll}
\hline $\begin{array}{l}\text { CFS Dimension: } \\
\text { Program support } \\
\text { for education } \\
\text { system }\end{array}$ & $\begin{array}{l}\text { Stement: Supported by child friendly systems, policies, practices } \\
\text { aLE indicators }\end{array}$ \\
- & ethnic minority teachers are trained and receive employment as \\
primary and early childhood development teachers \\
-
\end{tabular}

\section{The rubrics approach}

In addition to incorporating MLE, it is also suggested that the use of rubrics to assess CFS indicators be developed (Figure 4). A rubric refers to a comprehensive type of rating scale for assessment:

which is a scoring guide with a set of guidelines that define and describe the important criteria of the component being assessed. Because rubrics set forth specific criteria, define precise requirements for meeting those criteria, and assign a rating to each level of performance, they provide assessors with an effective, objective method for evaluating items that do not generally lend themselves to objective assessment methods. Rubric indicators are designed to describe standards leading to an ideal state on that aspect that is being assessed (UNICEF, 2006, p. 14)

Rubrics are useful when trying to assess the processes along a developmental continuum. Scoring rubrics provide at least two benefits in that they can indicate the extent to which the indicator has been reached, and they can provide feedback for improvement (Moskal, 2000). 


\section{Figure 4}

Example, CFS framework inclusive of MLE indicator

CFS Dimension: Democratic participation

MLE Indicator: Ethnic minority parents and communities are able to participate more in their children's education

Activity 1: School develops with parents a home/school activity plan designed to promote and advocate for MLE.

\begin{tabular}{|c|c|c|c|}
\hline $\begin{array}{l}\text { Below Average } \\
\square\end{array}$ & Average & $\begin{array}{l}\text { Good } \\
\square\end{array}$ & $\begin{array}{l}\text { Very Good } \\
\square\end{array}$ \\
\hline $\begin{array}{l}\text { Families and } \\
\text { community members }\end{array}$ & $\begin{array}{l}\text { Families and } \\
\text { community members }\end{array}$ & $\begin{array}{l}\text { Families and } \\
\text { community members }\end{array}$ & $\begin{array}{l}\text { Families and } \\
\text { community members }\end{array}$ \\
\hline $\begin{array}{l}\text { know little about the } \\
\text { program. }\end{array}$ & $\begin{array}{l}\text { know little } \\
\text { aboutisepithe program } \\
\text { and are cautious, but } \\
\text { publicly support the } \\
\text { program's existence. }\end{array}$ & $\begin{array}{l}\text { are fully supportive } \\
\text { of the program and } \\
\text { have sufficient } \\
\text { knowledge to begin } \\
\text { to advocate and } \\
\text { provide leadership } \\
\text { for the program. }\end{array}$ & $\begin{array}{l}\text { are supportive, } \\
\text { knowledgeable,sepian } \\
\text { d consistently } \\
\text { demonstrate strong } \\
\text { leadership } \\
\text { advocacy for the } \\
\text { program. }\end{array}$ \\
\hline
\end{tabular}

Evidence sighted:

a). School has a copy of its home/school activities plan

b). Interview and meeting notes with parents, families and relevant school staff

c). Other (provide details)

Comments:

This evidence-referenced system gives meaning to achievement by referencing it to evidence which monitors growth or progress and measurement along a developmental continuum. Rather than just a check against summative checklist, the system describes the evidence. The evidence statement is a way of showing growth. The assessment of the CFSMLE indicators involves professional judgment about the growth with respect to a continuum of development and is based on a collection of evidence.

The three countries in this research all have MLE policy, but only Cambodia has worked on developing a CFS framework that is inclusive of MLE. In 2017 a draft framework was produced (Frawley, 2017) but at the time of writing it has yet to be ratified.

\section{Conclusion}

This paper has identified key themes and areas for action and inclusion on MLE within CFS dimensions and has placed the context of MLE within global declarations and conventions which emphasise the right of Indigenous and ethnic minority children to an education that is provided in their first language. The paper provides a comparison of CFS indicators across three countries - Cambodia, the Philippines, and Nepal. It has also aligned MLE principles, arguments and foci with CFS dimensions. Based on the development work undertaken in Cambodia the paper suggests an approach to reflect MLE aspects within CFS indicators using an evidence-based rubric to monitor progress along a developmental continuum.

The benefits of a CFS monitoring framework that explicitly includes and addresses MLE indicators is that in MLE schools it places Indigenous languages at the centre of schooling, and not at the periphery as an 'add-on' within the education policy and practice context. Adopting a rubrics approach to assessment of the indicators within the CFS monitoring framework is beneficial in that such an approach monitors progress and measurement along a developmental continuum. This approach presents a challenge though 
in that it requires from a systematic quality assurance perspective 'a new type' of inspector who, based on CFS-MLE indicators can provide a 'more detailed, more, regular, more continuous, more guiding' assessment (UNICEF, 2016). This requires appropriate and regular training in MLE, and an ongoing commitment to the primacy of Indigenous languages.

\section{References}

Barrett, A. \& Sørensen, T. (2015). Indicators for All? Monitoring Quality and Equity for a Broad and Bold Post-2015 Global Education Agenda. University of Bristol: Open Society Foundations.

Benson, C. (2002). Real and Potential Benefits of Bilingual Programmes in Developing Countries. International Journal of Bilingual Education and Bilingualism 5 (6), 303-317.

Benson, C. (2005) The Importance of Mother Tongue-based Schooling for Educational Quality. Background paper for the EFA Global Monitoring Report 2005. Paris: UNESCO.

Benson, C. \& Wong, K. (2017). Effectiveness of policy development and implementation of L1-based multilingual education in Cambodia. International Journal of Bilingual Education and Bilingualism, DOI: 10.1080/13670050.2017.1313191

CARE (n.d.) Multilingual Education. Retrieved from www.care-cambodia.org

Chabbott, C. (2004). UNICEF's Child-friendly Schools Framework: a desk review. New York: United Nations Children's Fund.

Dumaguete City Department of Education (n.d.) Child Friendly School Indicators. Retrieved from http://depeddumaguete.com.ph/index.php

Education for All [EFA] (2007). Education for All Global Monitoring Report 2008: Education for All by 2015. Will We Make It? Oxford: Oxford University Press

Frawley, J. (2016). Multilingual Education (MLE) and the Child Friendly Schools (CFS) policy: adding MLE indicators to the CFS indicator framework. Unpublished report.

Frawley, J. (2017). Child Friendly Schools (CFS) And Multilingual Education (MLE): The CFS-MLE Framework. Unpublished report.

Godfrey, E., Osher, D., Williams, L., Wolf, S., Berg, J., Torrente, C., Spier, E. \& Aber, J. (2011). Cross-national measurement of school learning environments: Creating indicators for evaluating UNICEF's Child Friendly Schools Initiative. Children and Touth Services Review, 34(3), 546-557.

Godfrey, E. B., Osher, D., Williams, L. D., Wolf, S., Berg, J. K., Torrente, C., Spier, E. \& Aber, J. L. (2012). Cross-national measurement of school learning environments: Creating indicators for evaluating UNICEF's Child Friendly Schools Initiative. Children and youth services review, 34(3), 546-557

Government of Nepal (2010). National Framework of Child Friendly School for Quality Education. Retrieved from http://www.nnfsp.gov.np/PublicationFiles/2000a101a5 1e-43d3-859e-70a363a5a729.pdf

Kosonen, K. (2009, March). First Language-based multilingual education can help those excluded by language. In 12th APEID International Conference, Plenary Session IV: Bridging the Social Divide through Inclusive Education.

Lee, S., Watt, R. \& Frawley, J. (2014) Effectiveness of bilingual education in Cambodia: a longitudinal comparative case study of ethnic minority children in bilingual and monolingual schools, Compare: A Journal of Comparative and International Education, $45(4), 526-544$.

López Luis E. 2009. Reaching the unreached: Indigenous intercultural bilingual education in Latin America. Paper commissioned for the EFA Global Monitoring Report 2010.

Moskal, B. M. (2000). Scoring rubrics: what, when, and how? Practical Assessment, Research, \& Evaluation, 7(3). 
Ministry of Education, Republic of Maldives (2010). Health and safety quality indicators Child Friendly Baraabaru Schools, Maldives. UNICEF: Maldives

Ministry of Education and Youth and Sport (MoEYS) (2015a). Multilingual Education National Action Plan (MENAP) 2015-2018.

Ministry of Education and Youth and Sport (MoEYS) (2015b). Child Friendly Schools Policy for Basic Education 2015-2018

Ministry of Education and Youth and Sport (MoEYS) (2013). Prakas \#48 on identification of language for learners of Khmer nationality and ethnic minority origin.

Ministry of Education and Youth and Sport (MoEYS) (2007). Child Friendly School Policy.

Noorlander, J. (2008). The highland community education program. CARE Cambodia: Phnom Penh.

Pinnock, H., Mackenzie, P., Pearce, E. \& Young, C. (2011). Closer to home: How to help schools in low- and middle-income countries respond to children's language needs. London: Save the Children, UK.

United Nations (2008). Declaration on the Rights of Indigenous Peoples. Retrieved from https://www.un.org/esa/socdev/unpfii/documents/DRIPS_en.pdf

UNESCO (2015). Education 2030: Incheon Declaration and Framework for Action:

Towards Inclusive and Equitable Quality Education and Lifelong Learning for All.

Retrieved from www.unesco. org/new/fileadmin/MULTIMEDIA

/HQ/ED/ED_new/pdf/FFA-ENG-27Oct15.pdf

UNHR (1989). Convention on the Rights of the Child. Retrieved from https://www.ohchr.org/en/professionalinterest/pages/crc.aspx

UNICEF (2016). Joint formative evaluation of Child-Friendly School policy implementation in Cambodia: Final Report. Retrieved from

https://www.unicef.org/cambodia/results_for_children_25974.html

UNICEF (2009). Manual: Child friendly schools. New York: UNICEF.

UNICEF (2006). Assessing Child-Friendly Schools: A guide for programme managers in East Asia and the Pacific. Bangkok: Keen Publishing.

\begin{abstract}
About the Author
Jack Frawley is an Education Consultant based in Sydney, Australia. He has a national profile as researcher and writer in the areas of leadership and intercultural studies evidenced by his involvement in significant research and professional projects, consultancies, book chapters, refereed articles, and other publications. He has presented at several national and international conferences and continues to publish on, and participate in, leadership-related research projects. Jack holds Adjunct appointments at the University of Canberra and the Batchelor Institute.
\end{abstract}

